\title{
Use of Nutrients and Plant Extract to Manage Okra Yellow Vein Mosaic Disease (OYVMD) in Sargodha, Punjab, Pakistan
}

\author{
Iram Bilqees ${ }^{1}$, Yasir Iftikhar ${ }^{1}$, Mustansar Mubeen ${ }^{1,2 *}$, Qaiser Shakeel ${ }^{3}$, Ashara Sajid ${ }^{1}$, Zahoor Hussain $^{4}$, \\ Aqleem Abbas', Muhammad Aamir Sohail'², Judith Jeruto Kiptoo ${ }^{5}$ and Shehzad Iqbal ${ }^{2}$
}

${ }^{1}$ Department of Plant Pathology, College of Agriculture, University of Sargodha, Sargodha, 40100, Pakistan; ${ }^{2}$ State Key Laboratory of Agricultural Microbiology and Provincial Key Laboratory of Plant Pathology of Hubei Province, College of Plant Science and Technology, Huazhong Agricultural University, Wuban, 430070, Hubei, P.R. China; ${ }^{3}$ Department of Plant Pathology, University College of Agriculture and Environmental Sciences, The Islamia University Bahawalpur, Bahawalpur, Pakistan; ${ }^{4}$ Department of Horticulture, College of Agriculture, University of Sargodha, Sargodha, 40100, Pakistan; ${ }^{5}$ School of Biological and Physical Sciences, University of Nairobi, Nairobi, Kenya.

Abstract | Okra yellow vein mosaic disease (OYVMD) has been a menace to okra cultivation wherever grown in the world. This trial was carried out to monitor the disease severity, incidence and its management through different nutrients and plant extract. Plant extract and multi-nutrients were used to manage the disease to avoid the hazardous effect of chemicals on human health and being the eco-friendly. Four varieties of okra viz., Indian Rachna, Sabz Pari, Desi Bhindi, and Rama Krishna were grown under RCBD. Five treatments viz., $2 \%$ garlic extract, $2 \%$ multi-nutrients, silicon (1 and 1.5\%) s and water as control were applied. Sabz pari showed the maximum disease incidence of 50\% whereas, Indian Rachna with disease incidence of $25 \%$ exhibited the minimum DI. None of varieties showed immunity against the OYVMD. Among the treatments, multi-nutrients and garlic extract were effectively reduced the disease progression with the mean value of $7.42 \pm 0.91$ and $9.05 \pm 1.06$ respectively, as compared to control. These two treatments also reduced the disease severity with the mean value of $1.23 \pm 0.12$ and $2.00 \pm 0.21$ respectively. In conclusion, the cultivars Indian Rachna were resistant to OYVMV and its vector. The growers are advised to apply micronutrients along with the plant extracts to control these diseases to enhance the okra production.

Received | June 02, 2020; Accepted | September 04, 2020; Published | October 06, 2020

*Correspondence | Mustansar Mubeen, Department of Plant Pathology, College of Agriculture, University of Sargodha, Sargodha, 40100, Pakistan; Email: mustansar01@yahoo.com

Citation | Bilqees, I., Y. Iftikhar, M. Mubeen, Q. Shakeel, A. Sajid, Z. Hussain, A. Abbas, M.A. Sohail, J.J. Kiptoo and S. Iqbal. 2020. Use of nutrients and plant extract to manage okra yellow vein mosaic disease (OYVMD) in Sargodha, Punjab, Pakistan. Pakistan Journal of Agricultural Research, 33(4): 754-758.

DOI | http://dx.doi.org/10.17582/journal.pjar/2020/33.4.754.758

Keywords | Okra, OYVMD, Management, Multi-nutrients, Plant extract

\section{Introduction}

$\mathrm{O}$ $\mathrm{kra}$ (Abelmoschus esculentus (L.) Moench.) is known as villager's vegetable because of having seed protein and high amount of nutrition fiber. The common name of okra is lady finger. Okra belongs to the "Malvaceae" family. Okra is considered as nutritional power house due to its composition including minerals, vitamins and fiber contents. Its main vegetable cultivated in sub tropics, tropics and temperate area of world (Wammanda et al., 2010). It is grown all over the world as a vegetable crop such as India, Ghana, Nigeria, Pakistan and Egypt (FAO, 2014). In Pakistan, the cultivation of okra is on 13919 thousand hectares with 0.112 million tons production annually (Anonymous, 2013). Number of biotic and 
abiotic factors are involved in yield losses. Biotic factors involved number of pathogens and insects. The biotic factors which are responsible for disease developments in okra area as; fungi, viruses, bacteria, nematodes, mycoplasmas and mollicutes. Main cause of low yield of okra are these diseases including wilts, damping off, powdery mildews, leaf curls and leaf spots and okra yellow vein mosaic disease (Sheikh et al., 2013). The virus was initially reported from Bombay, India (Kulkarni, 1924; Mishra et al., 2017). OYVMV falls in genus Begomovirus (Naresh el al., 2019; Zerbini et al., 2005). Number of insects are involved in disease causing in okra such as jassid and leaf hopper etc., while the transmission of OYVMV occurs through the whitefly infestation in the field (Ghanem, 2003; Ullah et al., 2012). The observation of OYVMV on symptomology basis includes green and yellow patches, leaves with vein chlorosis and yellowish veins network with greenish island on the leaves. Severe infection leads to the whole leaf into yellowish color. The deformed and reduced fruit sized is produced after virus attack. The yield losses reached up to $80-90 \%$ in severe cases (Fajinmi and Fajinmi, 2010). Yield losses caused by OYVMV annually recorded in Pakistan ranged from 20-30\% (Ali et al., 2005). Chemical use is a vital practice to overcome the viral disease of okra and to increase the production of crop. OYVMV and whitefly (B. tabaci) can be controlled by modifying the cultural practices i.e. by modifying date of sowing and intercropping okra with cowpea. The whitefly population per plant can be kept in balance by using insecticides (Singh et al., 1983). The different spray internal controls the vector population and OYVMV. Excess use of chemicals which leads to the environmental pollution as well as poisonous to the all living organisms. An eco-friendly management such as plant extracts are now used to manage the disease which is more efficient and cost effective as compared to chemicals (Chaudhary et al., 2017). The present study was aimed to develop environment friendly management approach by using plant extract and micronutrients against OYVMD.

\section{Materials and Methods}

Germplasm used for experiment was commercially available in the grain market of Sargodha. Four commercially available varieties (Desi Bhindi, Indian Rachna, Sabz Pari, and Rama Krishna) from market were cultivated at research farm, College of Agriculture, University of Sargodha, Pakistan.
Randomized complete block design (RCBD) was the experimental design with three replications. The row to row distance and plant to plant distances of $1.5 \mathrm{ft}$ and $1 \mathrm{ft}$ respectively were maintained. All other routine agronomic practices were also performed.

\section{Disease incidence and severity}

The symptoms on the leaves of okra were continually observed and upon the appearance of the symptoms disease incidence and disease severity were recorded. Mosaic pattern, clearing of veins, small size fruit and stunted growth of plants was observed as symptoms described in literature. Disease incidence percent (DI) was recorded after symptom appearance by using the following formula (Ali et al., 2012).

$$
\text { Disease incidance }(\%)=\frac{\text { No. of infected plants }}{\text { Total number of plants }} \times 100
$$

Disease severity was measured following the disease rating scale (0-6) as shown in Table 1 (Ali et al.,2012).

\section{Treatments plan and preparation of garlic extract}

Five treatments such as; Silicon (1\%) as $\mathrm{T}_{1}$, Silicon (1.5\%) as $\mathrm{T}_{2}$, Multi-nutrients (2\%) as $\mathrm{T}_{3}$, Garlic extract (2\%) as $\mathrm{T}_{4}$ and control as $\mathrm{T}_{5}$ were used in disease management. All treatments were prepared by using distilled water while $T_{5}$ is only distill water spray used as control. Garlic extract was prepared using $25 \mathrm{~g}$ of peeled garlic grinding in $75 \mathrm{ml}$ of water. Filter the solution through the muslin cloth following the centrifugation at $13000 \mathrm{rpm}$ for $2 \mathrm{~min}$. Different nutrients; Zinc ( $\mathrm{Zn})$, Manganese (Mn), Iron ( $\mathrm{Fe}$ ), and boron (B) were applied as treatments. For the analysis of data, a statistical package STAT 8.1 was used.

\section{Results and Discussion}

The present study was carried out to evaluate the efficacy of nutrients and plant extracts in relation to disease progression and disease severity. Management trial was conducted in field with four okra varieties. Unfortunately, one variety named desi bhindi was unable to germinate. Therefore, three verities were used for the record of data. Symptomology was the criterion to record the disease incidence OYVMVD. Before treatments application, Sabz Pari with 50\% disease incidence was at the top and Indian Rachna with $25 \%$ showed least disease incidence. These varieties have no immune response against the disease (Table 2). 
Table 1: Disease rating scale for okra yellow vein mosaic virus.

$\begin{array}{llll}\text { Rating scale } & \text { Rating scale } & \text { Description } & \text { Response } \\ 0 & 0 \% & \text { With no symptoms on foliage of plants } & \text { Immune (I) } \\ 1 & 10 \% & \text { Scattered lesions from few to 10\% observed on plants } & \text { Highly resistant (HR) } \\ 2 & 11-25 \% & \text { Visible lesions up to 25\% on plants } & \text { Moderately resistant (MR) } \\ 3 & 26-50 \% & \text { Lesions more than } 25 \% \text { and up to } 50 \% \text { only } & \text { Tolerant (T) } \\ 4 & 51-60 \% & \text { Lesions from 50-60 } \% \text { + girdling of stem } & \text { Moderately susceptible (MS) } \\ 5 & 61-70 \% & \text { Vein yellowing initiation + mosaic on } 75 \% \text { plants } & \text { Susceptible (S) } \\ 6 & 71-100 \% & \text { Vein yellowing +mosaic with girdling of stem } & \text { Highly susceptible (HS) }\end{array}$

Table 2: Incidence of OYVMD incidence on okra varieties before treatment.

\begin{tabular}{|c|c|c|c|}
\hline \multirow[t]{2}{*}{ Varieties } & \multicolumn{2}{|c|}{ Incidence before treatment application (\%) } & \multirow[t]{2}{*}{ Mean (\%) } \\
\hline & Before two weeks & Before one week & \\
\hline Indian Rachna & 20 & 30 & 25 \\
\hline Sabz Pari & 40 & 60 & 50 \\
\hline Rama Krishna & 30 & 50 & 40 \\
\hline
\end{tabular}

Table 3: Effect of Plant extract and micronutrients on OYVMD incidence on three okra varieties.

\begin{tabular}{|c|c|c|c|c|c|c|c|c|c|c|c|c|}
\hline \multirow{3}{*}{$\begin{array}{l}\text { Treatments } \\
\text { Silicon } 1 \%\end{array}$} & \multicolumn{9}{|c|}{ Varieties } & \multicolumn{3}{|l|}{ Mean } \\
\hline & \multicolumn{3}{|c|}{ Indian Rachna } & \multicolumn{3}{|c|}{ Sabz Pari } & \multicolumn{3}{|c|}{ Rama Krishna } & \multirow[b]{2}{*}{9.75} & \multirow[b]{2}{*}{ \pm} & \multirow[b]{2}{*}{$1.10 \mathrm{AB}$} \\
\hline & 8.33 & \pm & 1.26 & 15.47 & \pm & 15.47 & 15.20 & \pm & 1.81 & & & \\
\hline Silicon $1.5 \%$ & 8.40 & \pm & 1.23 & 15.53 & \pm & 1.98 & 15.20 & \pm & 1.81 & 9.78 & \pm & $1.09 \mathrm{AB}$ \\
\hline Multi-nutrients $2 \%$ & 5.60 & \pm & 1.00 & 12.33 & \pm & 1.79 & 11.73 & \pm & 1.61 & 7.42 & \pm & $0.91 \mathrm{C}$ \\
\hline Garlic extract $2 \%$ & 7.40 & \pm & 1.23 & 14.60 & \pm & 2.00 & 14.20 & \pm & 1.81 & 9.05 & \pm & $1.06 \mathrm{~B}$ \\
\hline Control & 9.20 & \pm & 1.25 & 16.33 & \pm & 1.92 & 16.20 & \pm & 1.81 & 10.43 & \pm & $1.12 \mathrm{~A}$ \\
\hline Mean & 7.79 & \pm & $0.54 \mathrm{~B}$ & 14.85 & \pm & $0.86 \mathrm{~A}$ & 14.51 & \pm & $0.79 \mathrm{~A}$ & & & \\
\hline
\end{tabular}

Similar letters show non-significance at alpha level $(P>0.05)$.

Table 4: Effect of Plant extracts and nutrients on OYVMD severity on okra varieties.

\begin{tabular}{|c|c|c|c|c|c|c|c|c|c|c|c|c|}
\hline \multirow{3}{*}{$\begin{array}{l}\text { Treatments } \\
\text { Garlic extract } 2 \%\end{array}$} & \multicolumn{9}{|c|}{ Varieties } & \multicolumn{3}{|c|}{ Mean } \\
\hline & \multicolumn{3}{|c|}{ Indian Rachna } & \multicolumn{3}{|c|}{ Sabz Pari } & \multicolumn{3}{|c|}{ Rama Krishna } & \multirow[b]{2}{*}{2.00} & \multirow[b]{2}{*}{ \pm} & \multirow[b]{2}{*}{$0.21 \mathrm{~B}$} \\
\hline & 1.93 & \pm & $0.23 \mathrm{~d}$ & 3.00 & \pm & $0.35 c$ & 3.07 & \pm & $0.33 \mathrm{bc}$ & & & \\
\hline Silicon $1 \%$ & 1.93 & \pm & $0.23 \mathrm{~d}$ & 3.60 & \pm & $0.47 \mathrm{~b}$ & 3.60 & \pm & $0.45 b$ & 2.28 & \pm & $0.25 \mathrm{~B}$ \\
\hline Silicon $1.5 \%$ & 1.93 & \pm & $0.23 \mathrm{~d}$ & 3.60 & \pm & $0.47 \mathrm{~b}$ & 3.60 & \pm & $0.45 b$ & 2.28 & \pm & $0.25 \mathrm{~B}$ \\
\hline Multi-nutrients $2 \%$ & 1.33 & \pm & $0.13 \mathrm{e}$ & 1.80 & \pm & $0.20 \mathrm{de}$ & 1.80 & \pm & $0.17 \mathrm{de}$ & 1.23 & \pm & $0.12 \mathrm{C}$ \\
\hline Control & 2.93 & \pm & $0.23 \mathrm{c}$ & 4.20 & \pm & $0.37 \mathrm{a}$ & 4.27 & \pm & $0.40 \mathrm{a}$ & 2.85 & \pm & $0.27 \mathrm{~A}$ \\
\hline Mean & 2.01 & \pm & $0.11 \mathrm{~B}$ & 3.24 & \pm & $0.19 \mathrm{~A}$ & 3.27 & \pm & $0.19 \mathrm{~A}$ & & & \\
\hline
\end{tabular}

Same letters in the row or in a column show non-significance at alpha level $(P>0.05)$.

Our results were in confirmation of work performed by Mastoi et al., 2013 and Mubeen et al., 2017. They performed field experiment on six okra varieties (Sharmeeli, Ambak Sabzpari, Noori-786, Pusa sawani, Super green) against OYVMD and whitefly population. Results revealed that the Sabz Pari showed minimum DI and whitefly population and disease incidence, while Noori-786 showed the maximum response in both case. The nutrients and plant extracts are useful practice to manage plant diseases and pest population. The micronutrients enhance the vigor of plant and make the plant immune system strong against disease. In our current studies, different treatments were applied to minimize the disease incidence and disease severity; results showed that garlic extract (2\%) and multi-nutrients (2\%) 
significantly reduced disease incidence with the mean values of $9.05 \pm 1.06$ and $7.42 \pm 0.91$, respectively as compared to control. Effect of $1 \%$ silicon and $1.5 \%$ silicon were statistically at par with control treatment for progression in disease incidence with the mean values of $9.75 \pm 1.10$ and $9.78 \pm 1.09$ respectively (Table 3). There was significantly reduction in disease severity with multi-nutrients (2\%) and garlic extract $(2 \%)$ with the mean values of $1.23 \pm$ 0.12 and $2.0 \pm 0.21$ respectively, whereas effect of $1 \%$ silicon and $1.5 \%$ silicon were at par with control treatment with the mean value $2.28 \pm 0.25$ and 2.28 \pm 0.25 respectively (Table 4 ). Our results were in accordance of Chaudhary et al. (2017). They observed disease incidence on four varieties of Okra. Sabz pari and Pahuja among the four varieties of okra, were found in moderately resistant and tolerant category respectively, whereas Pusa sawani and Lush green response was susceptible and moderately susceptible respectively. They also used different plants extract such as onion, garlic, ginger and neem to manage OYVMD and its vector. Among those, plants extract garlic and neem extract at 5\% significantly reduced the whitefly population and disease incidence. Islam et al. (2002) applied Zinc and boron to minimize the incidence and severity of mungbean yellow mosaic virus (MYMV) and strongly recommended boron for the management of Mung bean yellow mosaic disease (Pramanik and Ali, 2010; Kumar et al., 2017). Different plant extracts such as Datura stramonium, Allium sativum, Eucalyptus globules, Aloe barbadensis Mill, Calotropics procera, salicylic acid (0.02\%) and Azadirachta indica have been used (Ali et al., 2010) against CLCuD and its vector Bemisia tabaci. Results showed that Allium sativum extracts were less effective as compared to salicylic acid and Azadirachta indica against vector and $\mathrm{CLCuD}$. It was also helpful in reducing the whitefly population and consequently reducing the okra leaf curl disease (Asare-Bediako et al., 2014). Ali et al. (2005) monitored the response of four okra cultivars (Subz Pari, Safal, Surkh Bhindi and Pahuja) against OYVMD and to check the effectiveness of different pesticide and/or biopesticides such as neem extract, imidacloprid and effective microbes against the whitefly population. Results revealed that Pahuja was tolerant, Safal, Sabz Pari MR and Surkh Bhindi were resistant to OYVMD. Among the pesticide or bio-pesticide, the neem extracts and microbes were less effective however imidacloprid has significant effects on the whitefly population as compare to control.

\section{Conclusions and Recommendations}

The use of resistant cultivar such as Indian Rachna is the best disease management strategy against OYVMV disease and its vector. Among all nutrients and plant extracts, multi-nutrients and garlic extract at $2 \%$ exhibited the best response to minimizing the disease incidence and disease severity against OYVMV disease. The Indian Rachna cultivar exhibited lowest disease incidence against OYVMD, having said that, the Phyto-pathologists and plant breeders should expand their work to explore more resistance varieties against the disease. The farmers are suggested to apply micro nutrients and plant extract for control.

\section{Novelty Statement}

In our research we observed that the Indian Rachna was best resistant cultivar against OYVMV disease and its vector. The micro nutrients and plant extract are ecofriendly and economically approaches against OYVMD.

\section{Author's Contribution}

Yasir Iftikhar and Mustansar Mubeen wrote the manuscript. Yasir Iftikhar and Qaisar Shakeel designed the experiment. Iram Bilqees, Zahoor Hussain and Ashara Sajid conducted the research. Shehzad Iqbal, Judith Jeruto Kiptoo and Muhammad Aamir Sohail analysis the data. Aqleem Abbas read and edited the final version of the manuscript.

\section{Conflict of interest}

The authors have declared no conflict of interest.

\section{Reference}

Ali, S., M.A. Khan, A. Habib, S. Rasheed and Y. Iftikhar. 2005. Management of yellow vein mosaic disease of okra throughpesticide/biopesticide and suitable cultivars. Int. J. Agric. Biol., 7: 145-147.

Ali,M.I.,M.A. Khan,A.Rashid,M.E.U.Haq,M.T. Javed and M. Sajid. 2012. Epidemiology of okra yellow vein mosaic virus and its management through Tracer, Mycotal and Imidacloprid. Am. J. Plant Sci., 3: 1741-1745. https://doi. org/10.4236/ajps.2012.312212

Ali, S., M.A. Khan, S.T. Sahi and M.U. Hassan. 2010. Evaluation of plant extracts and salicylic 
acid against bemisia tabaci and cotton leaf curl virus disease. Pak. J. Phytopathol., 22(2): 98100.

Anonymous, 2013. Economic survey: Govt. of Pakistan, economic advisor's wing, finance division, Islamabad, Pakistan.

Asare-Bediako, E., A.Addo-Quaye and A. Bi-Kusi. 2014. Comparative efficacy of plant extracts in managing whitefly (Bemisia tabaci Gen) and leaf curl disease in okra (Abelmoschus esculentus L). Am. J. Agric. Sci. Technol., 2(1): 31-41. https://doi.org/10.7726/ajast.2014.1004

Chaudhary, A., M.A. Khan and B. Yousaf. 2017. Management of okra yellow vein mosaic virus and its vector through plant extracts. J. Plant Pathol. Microbiol., 8: 393. https://doi. org/10.4172/2157-7471.1000393

FAO, 2014. FAOSTAT database. Available from http. //faostat: fao.org.

Fajinmi, A.A and O.B. Fajinmi. 2010. Incidence of okra mosaic virus at different growth stages of okra plants (Abelmoschus esculentus L. Moench) under tropical condition. J. Gen. Mol. Virol., 2: 28-31.

Ghanem, G.A.M., 2003. Okra leaf curl virus: A monopartite begomovirus infecting okra crop in Saudi Arabia. Arab J. Biotechnol., 6: 139152.

Islam, M.R., M.A. Ali, M.S. Islam and A.F.M.G.F. Hossain. 2002. Effect of nutrients and weeding on the incidence of mungbean mosaic. Plant Pathol. J., 1: 48-50. https://doi.org/10.3923/ ppj.2002.48.50

Kulkarni, G.S., 1924. Mosaic and other related diseases of crops in the Bombay Presidency. Poona Agric. Coll. Mag., 16: 6-12.

Kumar, A., R.B. Verma, R. Kumar, S.K. Sinha and R. Kumar. 2017. Yellow vein mosaic disease of okra: A recent management technique. Int. J. Plant Soil Sci., 19:1-8.https://doi.org/10.9734/ IJPSS/2017/35387

Mastoi, A.H., S.A. Memon and W. Haq. 2013. Varietal resistance of okra against whitefly (Bemisia tabaci) and fruit borer (Earias spp.). Sch. J. Agric. Sci., 3: 78-82.

Mishra, G.P.,B.Singh,T.Seth,A.K.Singh,J.Halder, N. Krishnan, S.K. Tiwari and P.M. Singh. 2017. Biotechnological advancements and begomovirus management in okra (Abelmoschus esculentus L.), status and perspectives. Front. Plant Sci., 8: 360. https://doi.org/10.3389/ fpls.2017.00360

Mubeen, M., Y. Iftikhar, M.I. Ullah, Q. Shakeel, M. Aatif and I. Bilqees. 2017. Incidence of okra yellow vein mosaic disease in relation to insect vector and environmental factors. Environ. Ecol., 35: 2215-2220.

Naresh, M., Z.A. Khan, R. Kumar, S.P. Kale, V.M. Patil, J.C. Rajput and I. Dasgupta. 2019. Occurrence and variability of begomoviruses associated with bhendi yellow vein mosaic and okra enation leaf curl diseases in south-western India. Virus Dis., 30(4): 511-525. https://doi. org/10.1007/s13337-019-00551-4

Singh, R., H.C. Singh and R.R. Singh. 1983. Effect of yellow vein mosaic virus on nitrogen and carbohydrate metabolism of Bhindi. Indian J. Mycol. Pla. Pathol., 13: 179-182.

Sheikh, M.A., S.Z. Khan and I. Mahmood. 2013. Effect of bhendi yellow vein mosaic virus on yield components of okra plants. J. Plant Pathol., 95: 391-393.

Steel, R., J. Torrie and T. Dickey. 1997. Principles and practice of statistics: A biomedical approach. New York: McGraw Hill.

Pramanik, B.K. and A. Ali. 2010. Cultural and nutritional management of yellow mosaic in winter mungbean. Pak. J. Biol. Sci., 4: 59-62. https://doi.org/10.3923/pjbs.2001.59.62

Ullah, S., H. Javed and M.A. Aziz. 2012. Role of physico-morphic characters of different okra genotypes in relation to population of jassid, amrasca biguttula biguttula ishida. J. Agric. Res., 50: 217-224.

Wammanda, D.T., A.M. Kadams and P.M. Jonah. 2010. Combining ability analysis and heterosis in a diallel cross of okra (Abelmoschus esculentus L. Moench). Afr. J. Agric. Res., 5: 2108-2115.

Zerbini, F.M., E.C. Andrade, D.R. Barros, S.S. Ferreira, A.T.M. Lima, P.F. Alfenas and R.N. Mello.2005. Traditional and novel strategies for geminivirus management in Brazil. Australas. Plant Pathol., 34: 475. https://doi.org/10.1071/ AP05088 